\title{
What Affects Water Quality In the Upper Colorado River Basin?
}

\author{
-Lori E. Apodaca, Verlin C. Stephens, and Nancy E. Driver
}

The Upper Colorado River Basin is 1 of 60 study units selected for water-quality assessment by the U.S. Geological Survey as part of the National Water-Quality Assessment program. Understanding the environmental setting of the Upper Colorado River Basin study unit is important in evaluating water-quality issues in the basin. Information about the environmental setting identifies the basin characteristics and includes natural and human factors that affect the physical, chemical, and biological quality of water in the basin. This information has been used to design surface-water- and ground-water-quality sampling networks in the basin to assess overall water quality of the basin.

\section{INTRODUCTION}

In 1991, the U.S. Geological Survey (USGS) began to implement the National Water-Quality Assessment (NAWQA) program. Goals of the NAWQA program are to (1) describe water-quality conditions for a large part of the Nation's freshwater streams, rivers, and aquifers; (2) describe how water quality is changing over time; and (3) improve the understanding of the primary natural and human factors that affect water-quality conditions (Leahy and others, 1990). To complete this program, the USGS plans to investigate 60 river basins and aquifer systems (study units) throughout the United States. Information obtained from these different study units will help Federal, State, and local agencies make needed management, regulatory, and monitoring decisions to better protect, use, and enhance water resources. This fact sheet, based on Apodaca and others (1996), describes how the environmental setting of the Upper Colorado River Basin (UCOL) study unit affects water quality in the basin. Information about the environmental setting, which is based on natural and human factors, was used to design surface-water- and ground-water-quality sampling networks for the study unit.

The UCOL study unit, located in western Colorado, has a drainage area of about 17,800 square miles (fig. 1). The primary river within the basin, the Colorado River, originates in the mountains of central Colorado and flows about 230 miles southwest into Utah. Major tributaries to the Colorado River are the Blue, Eagle, Roaring Fork, and Gunnison Rivers. In 1990, population in the basin was about 234,000 (Bureau of Census, 1990). The largest population center in the basin is the area around Grand Junction, Colo.

\section{ENVIRONMENTAL SETTING}

The environmental setting of the UCOL study unit provides a framework for understanding the basin characteristics, which are important in the design of an integrated study of the surface water and ground water of the basin. Natural factors that affect background water-quality conditions in the UCOL basin are physiography, climate, geology, and soils. Human factors that affect water-quality conditions are water management and use and land use in the basin.

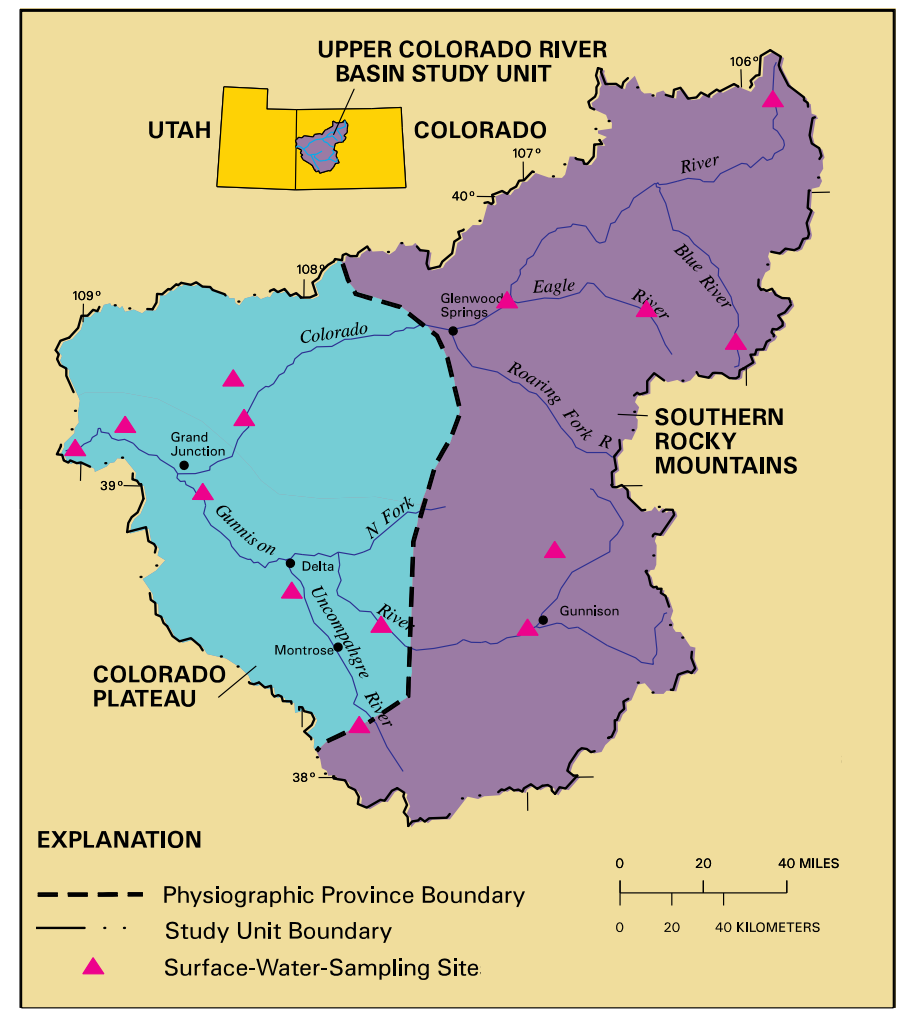

Figure 1. Location of the Upper Colorado River Basin study unit. 


\section{NATURAL FACTORS}

Thunderstorms in arid environments, such as in the western part of the UCOL study unit, cause large suspended-sediment loads in streams. Natural hot springs contribute about 500,000 tons of dissolved solids (15 percent of the total salinity) annually to the streams in the basin.

\section{Physiography and Climate}

The physiography is characterized by high mountains in the east and plateaus and valleys in the west. Two physiographic provinces divide the study unit: the Southern Rocky Mountains in the eastern part and the Colorado Plateau in the western part (fig. 1). The eastern and southern boundaries of the study unit follow the Continental Divide. Because of large differences in altitude between the physiographic provinces, climate varies substantially between the eastern and western parts of the basin. Daily, monthly, and annual average temperatures are highest at the lower altitudes to the west. Climate changes from alpine conditions in the east to semiarid to arid conditions in the west. Precipitation generally ranges from 40 inches or more per year in the eastern part of the basin to less than 10 inches per year in the western part of the basin (fig. 2).

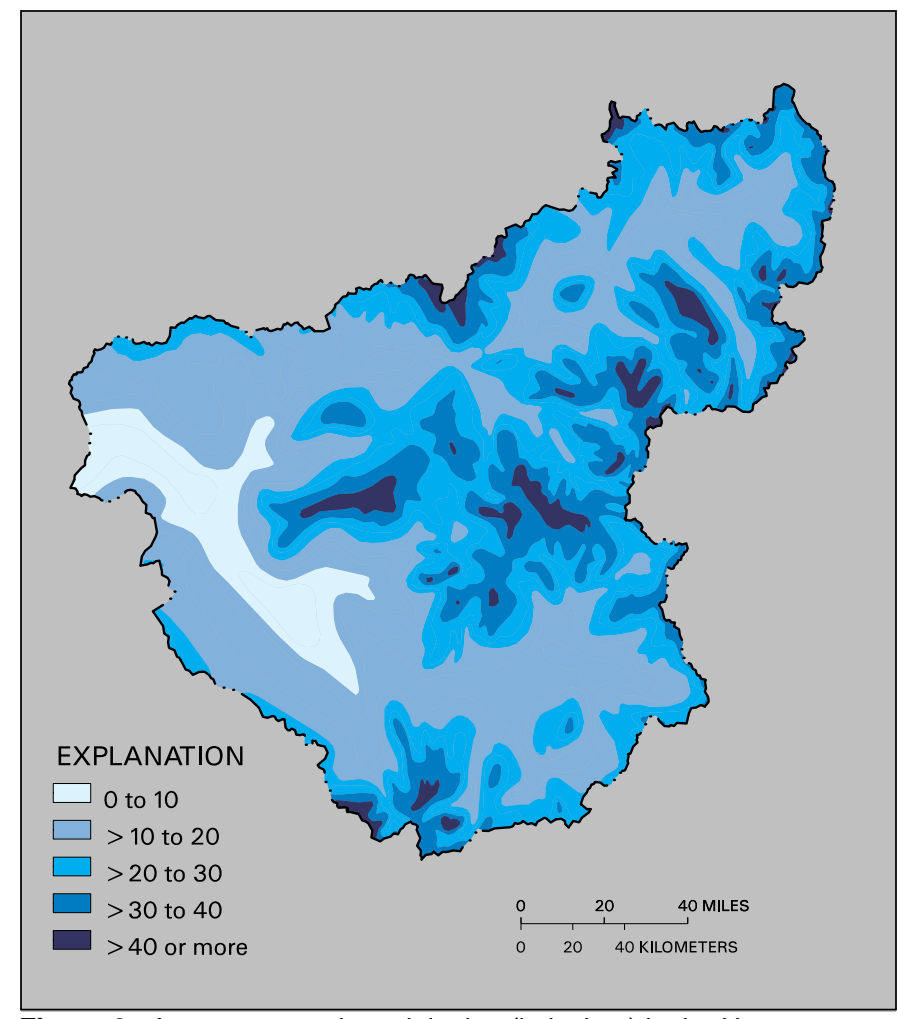

Figure 2. Average annual precipitation (in inches) in the Upper Colorado River Basin study unit (Colorado Climate Center, 1984).

\section{Geology and Soils}

The underlying bedrock in the study unit consists predominantly of crystalline and sedimentary rocks. Alluvium, consisting of stream, landslide, terrace, and glacial deposits, is present in valleys throughout the basin. In figure 3, the bedrock geology has been divided into igneous and metamorphic rocks; sedimentary rocks (further subdivisions of this unit were made if a predominant rock type of carbonate, sandstone, or shale was identified); intrusive rocks (often associated with mineral deposits); and volcanic rocks.
Weathering of the different geologic units affects water-quality conditions in the study unit. The igneous and metamorphic rocks of the upper basin contribute fewer solutes to the streams than do the sedimentary rocks of the lower basin. At higher altitudes in the upper basin, exposed igneous, metamorphic, and volcanic rocks are fairly resistant to weathering, and thus salinity in the water is low in these upper stream reaches. Also, mineralized areas in the upper basin contribute trace elements to the surface and ground waters.

When the streams come in contact with outcrops of sedimentary rocks in the middle and lower reaches of the basin, salinity in the water increases. In the more arid climate at lower altitudes in the western part of the basin, precipitation commonly is in the form of thunderstorms, and runoff from thunderstorms can deliver large loads of sediment and salts to the streams. In addition, evaporation in this arid climate enhances the accumulation of salts on the soil, which then can be delivered to streams during storm runoff. Selenium is present naturally in the shale bedrock of the middle and lower reaches, and it occurs in the surface and ground waters.

The presence of many mineral springs in the study unit also has a major effect on water quality. The springs primarily are located in carbonate rock units in the area surrounding Glenwood Springs, Colo. (figs. 1 and 3). The mineral hot springs contribute about 15 percent of the total salinity annually to the streams in the basin (U.S. Department of the Interior, 1995).

Soils also can affect water quality because soils can be a source of suspended sediment and soluble materials (salts). Suspended sediment in streams predominantly is a result of channel erosion and soil erosion from storm runoff. Generally, suspended-sediment concentrations in streams increase from the eastern edge of the Colorado Plateau physiographic province to the outflow of the basin at the Colorado-Utah State line. Soluble materials are added to the streams by storm runoff.

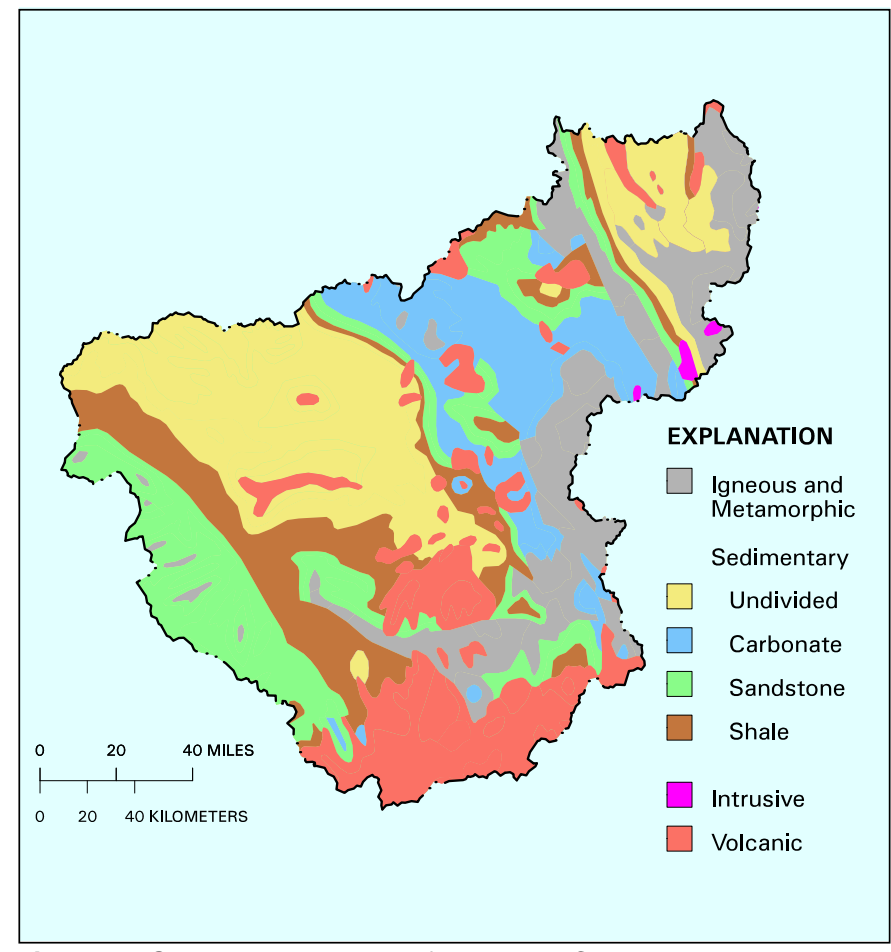

Figure 3. Generalized geology of the Upper Colorado River Basin study unit (modified from Schruben and others, 1974). 


\section{HUMAN FACTORS}

Mining is a source of trace metals; urbanization is a source of nutrients and organic chemicals; and agriculture is a source of salinity and nutrients to aquifers and streams, and suspended sediments to streams.

Interbasin water transfers, mining, urbanization, and agriculture are the principal human activities that affect water quality in the UCOL study unit. In the study unit, these activities occur approximately in a downstream order. Interbasin water transfers are in the headwaters, mining occurs in the mountainous areas, urbanization is in the valleys of the Southern Rocky Mountains and Colorado Plateau, and agriculture predominantly is in the valleys of the Colorado Plateau.

\section{Water Management and Use}

In 1993, interbasin water transfers (fig. 4) conveyed about 585,000 acre-feet of water (12 percent of the average annual streamflow of the basin) from the Upper Colorado River Basin to the South Platte, Rio Grande, and Arkansas River Basins. Interbasin water transfers generally occur near the stream headwaters, and the amount of streamflow diverted can be a substantial part of the streamflow near these sources. By removing water from the system, interbasin water transfers decrease the dilution capability of the streams. The numerous reservoirs, water diversions, and municipal discharges in the basin (fig. 4) alter the natural streamflow, which can affect the aquatic habitat and water quality of the streams. For example, reservoirs can trap sediment and decrease trace-metal loads downstream.

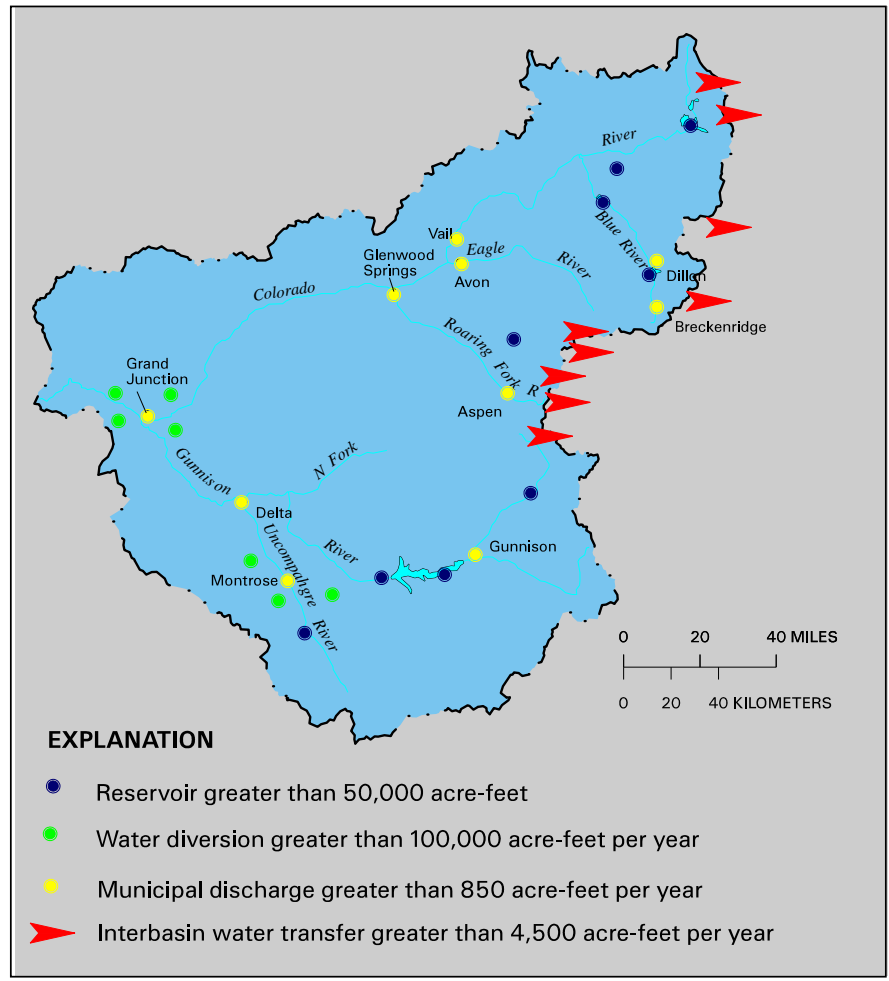

Figure 4. Major water storages, uses, and exports in the Upper Colorado River Basin study unit.
Water used in the study unit predominantly is from surfacewater sources; however, ground water, which accounts for about 1 percent of the total water used in the basin, is important for domestic use in rural communities. Irrigation is the principal offstream water use in the basin, which accounted for about 97 percent of all water use in 1990.

\section{Land Use}

Rangeland and forest (fig. 5) are the predominant land uses in the study unit (about 85 percent). Livestock grazing, logging, and year-round recreational activities on rangeland and forest can affect the water quality by adding sediments, nutrients, and other constituents to the water.

Metal mining is an important activity that occurs in the headwater areas of the basin. Past and present mining activities have included the extraction of metals such as copper, gold, lead, molybdenum, nickel, silver, vanadium, and zinc. Several tributaries to the Colorado River-the Blue, Eagle, Roaring Fork, and Gunnison Rivers - drain one of the primary metal-mining regions in Colorado. Streams in the basin have been affected by point-source mine discharge and nonpoint-source runoff from mined areas (Wentz, 1974). Some streams in the basin, such as Red Mountain Creek (a tributary to the Uncompahgre River), are affected by acid mine drainage.

Urbanization is one of the smaller land uses in the mostly rural Upper Colorado River Basin. However, in some mountain communities in the headwaters of the study unit, the population is increasing at a rate of about 10 percent annually (Bureau of Census, 1992). Point sources from urbanization include discharge from wastewater-treatment plants, leachate from septic systems, solidwaste disposal, leaking underground storage tanks, industrial discharges, and storm runoff, which also is a nonpoint source. All these sources potentially can affect the surface and ground water by adding nutrients, pesticides, various chemicals, hydrocarbons, trace elements, and salts depending upon the specific point source.

Agriculture, predominantly in the Colorado Plateau physiographic province, is an important land use (about 7 percent of this physiographic province). There are several potential agricultural nonpoint-source issues in the lower region of the basin. Agricultural activities in the basin can cause increased levels of salinity, sediments, nutrients, pesticides, and selenium and other trace elements in receiving waters, which can affect the surface- and ground-water quality and aquatic biota. For example, irrigation return flows can increase salinity in the surface and ground waters of the study unit. In addition, partly because of reuse of irrigation water and leaching of naturally occurring trace elements from the soils and underlying shale bedrock, trace elements, such as selenium, are present in the water used for domestic and irrigation purposes. Selenium concentrations are high in the lower valleys of the basin, which also can be a concern for protection of fish and waterfowl. In the semiarid to arid climates of the Colorado Plateau, suspended sediment in the streams, as a result of sediment erosion by wind and water, can be increased by agricultural activities. 


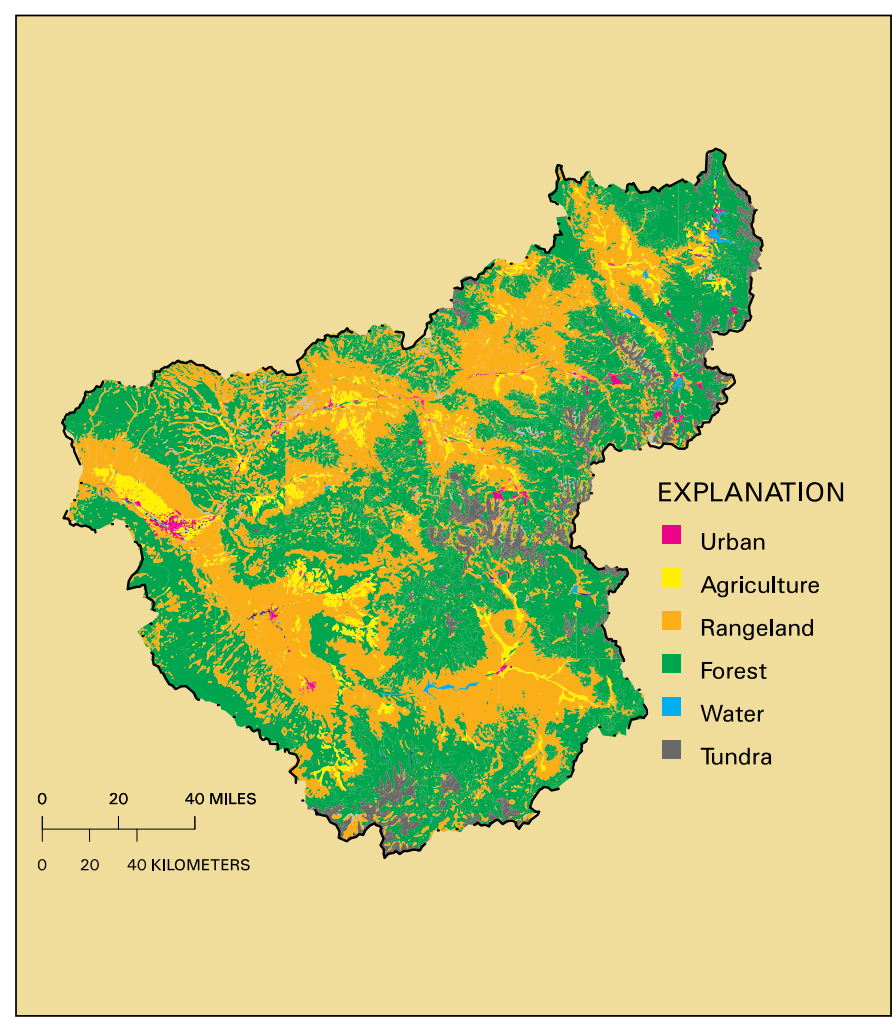

Figure 5. Land use in the Upper Colorado River Basin study unit (modified from Marschner, 1967).

\section{SELECTION OF WATER-QUALITY SITES}

Results from evaluation of the environmental setting were used to design the surface-water- and ground-water-quality sampling networks for the UCOL study unit. For the surface-water-quality sampling network (fig. 1), 14 sites have been established to assess natural background water-quality conditions; effects of mining, urban/recreational, and agricultural land uses; and the water quality of larger streams that integrate multiple land uses upstream from the sampling site. Sampling selection was based on drainage area, land use, amount of available data, importance to local, State, and Federal agencies, extent of ongoing and past studies in the area, and ability to compare the water-quality data collected in the basin with the other study units of the NAWQA program on a national perspective. Flow characteristics; concentrations and loads of nutrients, major ions, metals, and suspended sediment; and aquatic biological communities will be measured, sampled, or described at these sites.

Ground-water sampling will focus on the effects of mining, urban, and agricultural land uses on the shallow ground-water quality in the basin. For the ground-water-quality sampling network, about 30 wells will be sampled for selected land uses in the UCOL basin. In contrast, a general assessment of major ground-water sources in the Southern Rocky Mountains physiographic province of the basin also is planned, with about 30 wells to be sampled. The general assessment sampling will investigate both natural and human factors on water quality.

\section{References Cited}

Apodaca, L.E., Driver, N.E., Stephens, V.C., and Spahr, N.E., 1996, Environmental setting and implications on water quality, Upper Colorado River Basin, Colorado and Utah: U.S. Geological Survey Water-Resources Investigations Report 95-4263, 33 p.

Bureau of Census, 1990, 1992, 1990-1992 census of population and housing: Washington, D.C., data on CD-ROM.

Colorado Climate Center, 1984, Colorado average annual precipitation 1951 to 1980: Fort Collins, Colorado Climate Center, scale 1:500,000.

Leahy, P.P., Rosenshein, J.S., and Knopman, D.S., 1990, Implementation plan for the National Water-Quality Assessment Program: U.S. Geological Survey Open-File Report 90-174, 10 p.

Marschner, F.J., 1967, Major land uses of the United States, adapted from U.S. Department of Agriculture: National Atlas of the United States, p. 158-159, scale 1:7,500,000.

Schruben, P.G., Arndt, R.E., and Bawlec, W.J., 1974, Geology of the conterminous United States at 1:2,500,000—A digital representation of the 1974 P.B. King and H.M. Beikman map: U.S. Geological Survey Digital data series, DDS-11, on CD-ROM.

U.S. Department of the Interior, 1995, Quality of water Colorado River Basin—Progress report no. 17: U.S. Department of the Interior, $96 \mathrm{p}$.

Wentz, D.A., 1974, Effect of mine drainage on the quality of streams in Colorado, 1971-72: Water Conservation Board, Water Resources Circular 21, 117 p.

Information on technical reports and hydrologic data related to the NAWQA program can be obtained from:

\section{Upper Colorado River Basin NAWQA Manager} U.S. Geological Survey Bldg. 53, Denver Federal Center Mail Stop 415, Box 25046

Denver, CO 80225 (303) 236-2101 ext. 224 email: nedriver@usgs.gov

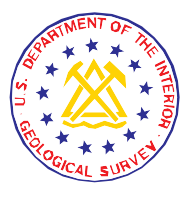

Web site: http://webserver.cr.usgs.gov/nawqa/ucol/ uco1_home.html 